\title{
The Causal Factors Underlying the Unwillingness of Farm Laborers' Migration to Towns: a Case Study of Yunnan Province
}

Li Shuo

School of Economics and Management, Southwest Forestry University, 650224 Kunming, China.

\begin{abstract}
Farmers' settling down in small towns is not only a process of identitychanging, i.e., from rural population into urban population, but also a process of institutional change. At present, China's urbanization rate is $52.57 \%$. However, in reality, the farm laborers do not often hold a positive and active view about migrating to the towns permanently. Statistics show that in 6 counties in Yunnan Shangri-La, Xishuangbanna, Lijiang border areas and 5 central Yunnan counties, the non-agricultural household staff does not grow very rapidly. By analyzing a lot of underlying factors, this paper finds that influential factors for the transformation of rural population to towns may vary, mainly including factors such as fewer jobs, the issue of rural land use, the poor quality of education, higher level of living standard, and also puts forward some solutions accordingly.
\end{abstract}

Keywords. small towns; migrant workers; enthusiasm; factors analysis

\section{The number of farm laborers' migration to small towns have a slow increase}

Yunnan Province is in the border of southwest China, with a total area of about 390,000 square kilometers, accounting for $4.11 \%$ china area, with a total population of 45,960,000 (2010), accounting for $3.35 \%$ of the china population, the population ranked $12 \mathrm{th}$. As of 2010 , the population living in towns was 1,618 million, $35.20 \%$ of the total population; population living in rural areas was $2,978.6$ million, $64.80 \%$ of the total population. By 2011, the number of province's urban is developed to 19 (including a large city, a big city, seven medium-sized cities, ten small cities), towns developed to 583 (including 118 county towns), the built area of urban reached 1458 square kilometers, the urban population reached 1704 million, the urbanization rate reached $36.8 \%$.

Figure 1.Schematic of Yunnan County area

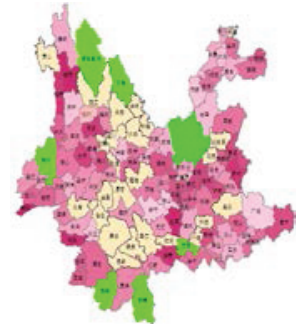

This is an Open Access article distributed under the terms of the Creative Commons Attribution License 2.0, which permits unrestricted use, distribution, and reproduction in any medium, provided the original work is properly cited. 
The study area (the green part of Figure 1) is divided into two parts, the first part of the area is the six counties of Yunnan frontier border zone, Xishuangbanna Menghai, Mengla, Baoshan Tengchong, Diqing Shangri-La County, Ninglang county of Lijiang and Yuanyang County of Red River, which borders part of the county and foreign, and all belong to minority frontier counties, this cities are not far from the center city. The second part of the Yunnan region is 5 counties,i.e., Luquan, Dongchuan, Fuming, Xundian and Songming, which is close to Kunming central city.

Since the gradual implementation of the Household registration reform program in Yunnan Province, the farm laborers do not often hold a positive and active view about migrating to the townspermanently,mainly, the growth of the number of migrant workers in small towns is unhappy, non-agricultural population growth is very slow.

\subsection{Non-agricultural population is growing displeasure in six frontier counties in Yunnan}

From the 6 frontier counties in Yunnan, the Tengchong, Shangri-La, Menghai, Mengla, Ninglang, Yuanyang were located in Yunnan frontier geographical location, low cost of living and other expenses here, but compared to the main city center settled, the number of farmers settled in counties will increase, in reality, the actual situation is not optimistic. See Table 1.

Table 1. 2005-2010 non-agricultural population statistics of 6Counties of Yunnan frontier

\begin{tabular}{|c|c|c|c|c|c|c|c|c|c|c|c|}
\hline & & & & & & & & & & & nit: million \\
\hline & 2005 & & 2006 & & 2007 & & 2008 & & 2009 & & 2010 \\
\hline & & & $\begin{array}{c}\text { Compared } \\
\text { with last } \\
\text { year }\end{array}$ & & $\begin{array}{c}\text { Compared } \\
\text { with last } \\
\text { year }\end{array}$ & & $\begin{array}{c}\text { Compared } \\
\text { with last } \\
\text { year }\end{array}$ & & $\begin{array}{c}\text { Compared } \\
\text { with last } \\
\text { year }\end{array}$ & & $\begin{array}{c}\text { Compared } \\
\text { with last } \\
\text { year }\end{array}$ \\
\hline Menghai & 4.64 & 4.44 & $-4.31 \%$ & 4.65 & $4.73 \%$ & 5.36 & $15.27 \%$ & 6.92 & $29.10 \%$ & 5.34 & $-22.83 \%$ \\
\hline Mengla & 7.1 & 7.2 & $1.41 \%$ & 7.24 & $0.56 \%$ & 7.28 & $0.55 \%$ & 7.34 & $0.82 \%$ & 7.35 & $0.14 \%$ \\
\hline Tengchong & 5.35 & 5.48 & $2.42 \%$ & 15.8 & $188.32 \%$ & 16.3 & $3.16 \%$ & 16.8 & $3.07 \%$ & 19.53 & $22.20 \%$ \\
\hline Shangri-La & 4.3 & 4.37 & $1.62 \%$ & 4.49 & $2.75 \%$ & 2.63 & $-41.42 \%$ & 2.65 & $0.76 \%$ & 2.68 & $1.13 \%$ \\
\hline Ninglang & 2.16 & 2.43 & $12.5 \%$ & 2.56 & $5.35 \%$ & 2.69 & $5.07 \%$ & 2.6 & $-3.35 \%$ & 2.7 & $3.85 \%$ \\
\hline Yuanyang & 1.02 & 1.96 & $92.16 \%$ & 1.9 & $-3.06 \%$ & 2.06 & $40 \%$ & 2.1 & $-21.05 \%$ & 2.1 & 0 \\
\hline
\end{tabular}

Source: 2006-2011 Yunnan Yearbook

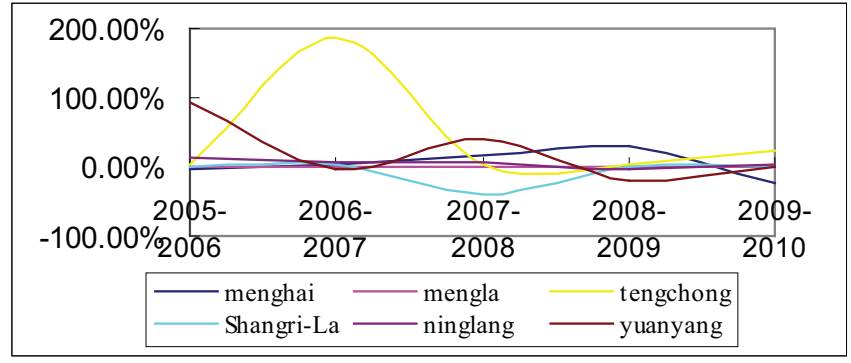

Figure 2. 2005-2010 non-agricultural population growth rate trend of Yunnan frontier County

Source:2006-2011 Yunnan Yearbook 
Statistical data from Table 1, we have a detailed understanding of the non-agricultural population of six frontier counties in Yunnan. According to the statistics in Table 1 are derived Figure 2,Figure 2 can be seen Tengchong county has increased the non-agricultural population in 2006-2007, but the growth is also showed a very gentle trend, which four counties have a negative growth situation in 2007-2010. In reality,farmers laborers do not often hold a positive and active view about migrating to the towns permanently.

\subsection{Non-agricultural population is growing displeasure in 5 counties in central Yunnan}

The 5 counties in central Yunnan are focused on the geographical district.The household registration policy will not be much different, various policies and measures, especially for the farmers closer into the city, focusing on the performance of the non-agricultural population. Table 2 below.

Table 2. 2004-2010 non-agricultural population statistics of Yunnan 5 counties

\begin{tabular}{|c|c|c|c|c|c|c|c|c|c|c|c|c|c|}
\hline & 2004 & \multicolumn{2}{|r|}{2005} & \multicolumn{2}{|r|}{2006} & \multicolumn{2}{|r|}{2007} & \multicolumn{2}{|r|}{2008} & \multicolumn{2}{|r|}{2009} & \multicolumn{2}{|r|}{2010} \\
\hline & & & $\begin{array}{c}\text { Compared } \\
\text { with last } \\
\text { year }\end{array}$ & & $\begin{array}{c}\text { Compared } \\
\text { with last } \\
\text { year }\end{array}$ & & $\begin{array}{c}\text { Compared } \\
\text { with last } \\
\text { year }\end{array}$ & & $\begin{array}{c}\text { Compared } \\
\text { with last } \\
\text { year }\end{array}$ & & $\begin{array}{c}\text { Compared } \\
\text { with last } \\
\text { year }\end{array}$ & & $\begin{array}{c}\text { Compared } \\
\text { with last } \\
\text { year }\end{array}$ \\
\hline Dongchuan & 70443 & 70442 & 0 & 71765 & $1.9 \%$ & 74202 & $3.4 \%$ & 73285 & $-1.2 \%$ & 73280 & 0 & 74454 & $1.6 \%$ \\
\hline Luquan & 25618 & 26191 & $2.2 \%$ & 26808 & $2.3 \%$ & 27053 & $0.9 \%$ & 26918 & $-0.5 \%$ & 26944 & $0.1 \%$ & 26833 & $-0.4 \%$ \\
\hline Xundian & 32511 & 33038 & $1.6 \%$ & 34440 & $4.2 \%$ & 35179 & $2.1 \%$ & 35594 & $1.3 \%$ & 35781 & $0.5 \%$ & 35949 & $0.5 \%$ \\
\hline Fuming & 18018 & 18550 & $2.9 \%$ & 18938 & $2.1 \%$ & 19163 & $1.2 \%$ & 19109 & $-0.3 \%$ & 19048 & $-0.3 \%$ & 18842 & $-1.1 \%$ \\
\hline Songming & 35886 & 35884 & 0 & 36353 & $1.3 \%$ & 36696 & $0.9 \%$ & 34989 & $-4.7 \%$ & 34857 & $-0.4 \%$ & 31929 & $-8.4 \%$ \\
\hline
\end{tabular}

Source: 2005-2011 Kunming Yearbook

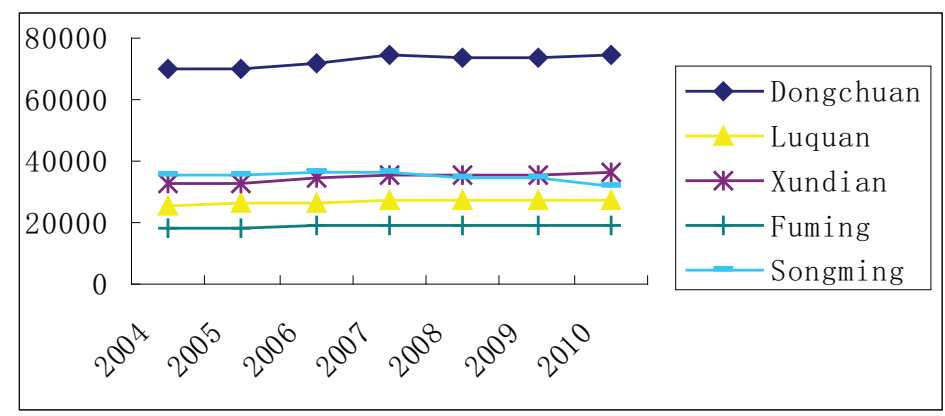

Figure 3. 2004-2010 total non-agricultural population growth of 5 counties of Yunnan center

Source: 2005-2011 Kunming Yearbook

From the statistics of above table 2, the number of non-agricultural population of 5 counties of central Yunnan had a little change in the 2004-2010 five-year period. i.e., Luquan County, Dongchuan, Fuming, Songming and Xundian county, and negative growth in 2008-2010, while from the results of the table 2 can be seen in Figure 3, it is the change trends of the non-agricultural population in 20042010 , the non-agricultural population of the five counties changes tending to straight line in Figure 3, so we can see the whole farmers laborers do not hold a positive and active view about migrating to the small towns permanently. 


\section{Several factors affect the enthusiasm of farmers settled in the small town}

\subsection{Fewer jobs in small town is paramount}

Without a stable job in the labor market of small towns developed, especially in remote regions of small towns. Because small towns do not have industrial, underdeveloped commercial, almost have no new jobs. Migrant workers could not find work that causing farmers of city without a stable source of jobs and income, on the other way, employment channels compared to counties and the capital city appear to be narrower, vocational education is more lag. Through several sets of data of the whole of Yunnan Province, the jobs are few so that small towns do not meet the needs of surplus labor, the number of new jobs and the transfer of rural labor force in small towns in Yunnan in 2011 are as follows. See the figure 4.

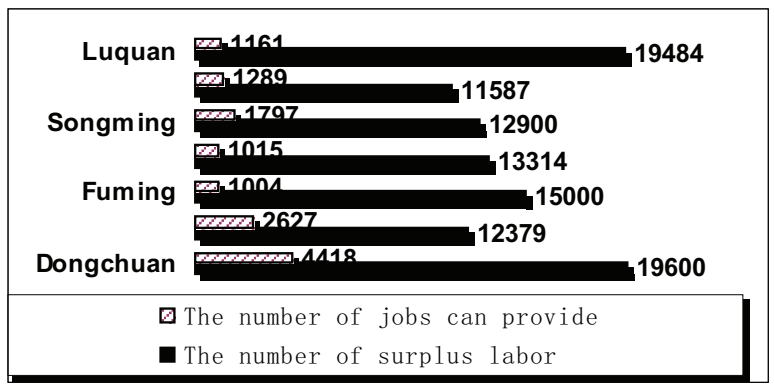

Figure 4. The number of new jobs and the transfer of rural labor force in small towns

Source:2011 Yunnan Economic and Social Development Statistics Bulletin

According to the chart we can see that the town has to offer jobs effectively is far from meeting the huge demand for migrant workers. Farmers settled in small towns do not have enough jobs to increase revenue, so basic needs might be a problem. Therefore, lack of jobs into the city has become the biggest obstacle to farmers.

\subsection{Infrastructure and the quality of education in small towns are poor and unattractive}

Although in recent years the financial situation of the Kunming outer suburbs has improved greatly, but the infrastructure investment in small towns of government taking still lacks the scale of construction, local government education funding is short, lack of standardization of small towns. The performance of the construction is the road, construction of drainage facilities, especially the poor quality of education in small towns. The number and the quality of teaching kindergarten urgent need a focus. The lack of tools kindergarten teaching facilities, outdated teaching venue has not been selected more stringent, there have been more than the status quo messy, kindergarten is not enough to establish a standard specification, size and layout is not reasonable, resulting in the widening gap between nursery education. Road construction did not have a reasonable system, water supply and drainage facilities are backward and have less landscaping area in small towns. Farmers settled in the city is hope to improve living conditions. When the above situationis are coming, the performance of farmers is not positive enough for the small town life that they are yearning for.

\subsection{In addition to working in the big cities, the leaving rural farmers now do not want to leave the countryside}

Complex homeland enthusiasm for Migrant Workers also have been affected, the farmers settled in town not only have to pay the economic costs, but also have to pay the performance of the 
psychological cost. The rural population of working in the big city is generally young adults, their homeland enthusiasm change out with the length of time, the time of working in big cities is longer and the homeland idea is weaker. And is now in rural areas, the farmers remain mostly older rural population, a long rural life may gradually dilute the idea that they go out, on the other hand, the way of life in rural areas and cities are very different, an invisible psychological barrier of urban and rural differences in the pace of life is now in the formation crowd, this problems has become negative factors for settling in the small town.

\subsection{The issues of the cost in small-town life}

Although the current household registration reform have much lower threshold, but the shift still belong to a high standard. Multi-aspect money for Small town prices rose and high consumption of urban life are the main problems. Lack of sufficient economic strength, the primary problem of farmers' housing can not be solved, resulting in the per capita consumption expenditure cost of living rose considerably. When the proportion of the increase in per capita consumption expenditure is greater than the increase in income than the column, it will weaken the aspire enthusiasm of farmers settled in the city. See Table 3.

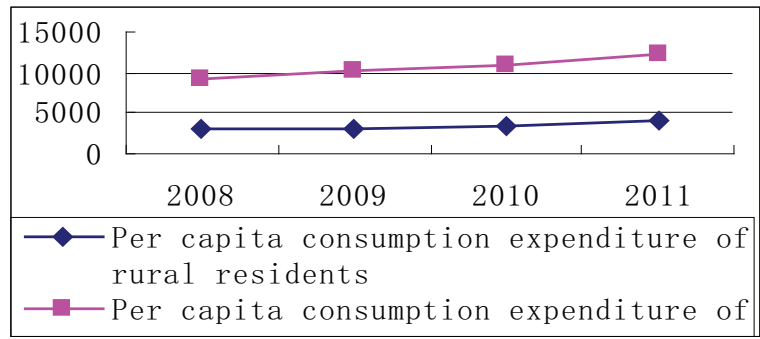

Figure 5. Per capita consumption expenditure of urban and rural residents in Yunnan

Source:2008-2011 Yunnan Economic and Social Development

Table 3. 2008-2011 Yunnan rural residents and urban residents living consumption indicators

\begin{tabular}{|c|c|c|c|c|c|c|c|}
\hline & 2008 & \multicolumn{2}{|c|}{2009} & \multicolumn{2}{|c|}{2010} & \multicolumn{2}{|c|}{2011} \\
\cline { 2 - 8 } & & & $\begin{array}{c}\text { Compare } \\
\text { d with } \\
\text { last year }\end{array}$ & & $\begin{array}{c}\text { Compare } \\
\text { d with } \\
\text { last year }\end{array}$ & \multicolumn{2}{c|}{$\begin{array}{c}\text { Compare } \\
\text { d with } \\
\text { last year }\end{array}$} \\
\hline $\begin{array}{c}\text { Per capita consumption } \\
\text { expenditure of rural residents }\end{array}$ & 2991 & 2925 & $-2.21 \%$ & 3398 & $16.2 \%$ & 4000 & $17.7 \%$ \\
\hline $\begin{array}{c}\text { Per capita consumption } \\
\text { expenditure of urban residents }\end{array}$ & 9077 & 10202 & $12.3 \%$ & 11074 & $8.5 \%$ & 12248 & $10.3 \%$ \\
\hline
\end{tabular}

Source: 2008-2011 Yunnan Economic and Social Development Statistics Bulletin

From the above Figure 5 can be drawn, it is the growth trends of the per capita consumption expenditure between Yunnan urban and rural residents, the life consumer spending of farmers settled into small town will be a sharp rise, per capita consumption exceeded million, while food, clothing, housing, medical care, transportation and communication and education as the main consumer spending. But this consumer spending in the city areas is general standard. If according to the $(\mathrm{R}=$ per capita income / capita consumption expenditure) in terms of farmers life into town, $\mathrm{R}$ is smaller and 
expenditure will seem more. It can be inferred that urbanization needs greatly increase for the cost of living.

\subsection{The scope of farmers' land is not in the government's planning}

The land use potential for the development of surrounding small towns is large, the government often will put it into the scope of government planning priorities. So a part of farmers can get a better land transfer subsidies for selling land, but for other farmers in more remote place, the land is their main social security. If the farmers of settled in city wants achieve land transfer, it is difficult to find a suitable way to to achieve this transfer process, because in this development positions, the use of the land will be in a bad cool performance and not in the planning for state government. Even if it can achieve this process, but the transfer of these subsidies is very low, and may be far less than the gain brought by cultivation.

In the eyes of farmers, this bad business make a lot of people continue to engage in traditional agricultural production, which obviously cannot raise the enthusiasm of farmers into the city.

\section{Countermeasures and Suggestions}

\subsection{For farmers settled in the small town, the key problem is to create more jobs in the labor force}

Government should vigorously develop small towns characteristic economy to create more jobs, introducing from industry with a certain specification, constructing industry and trade district towns, small towns are encouraged to start their own businesses, adding more financing channels and financial services platform.

Mining tourism, cultural industries and agriculture in small town in Yunnan, developing vocational skills training. The following chart reflects the development of the agricultural and industry makes more agricultural population changes into urban population, to better promote the farmers life of settled in the small towns. The figure 6 is the relationship charts that industry accounts proportion of the total economy of the region, and the agricultural population accounts for the proportion of the total population of the region's in the 6 frontier counties and five counties in Yunnan. As can be seen from the figure 6 , the proportion of agricultural population and industry share showing the inverse relationship. See the figure 7 below.

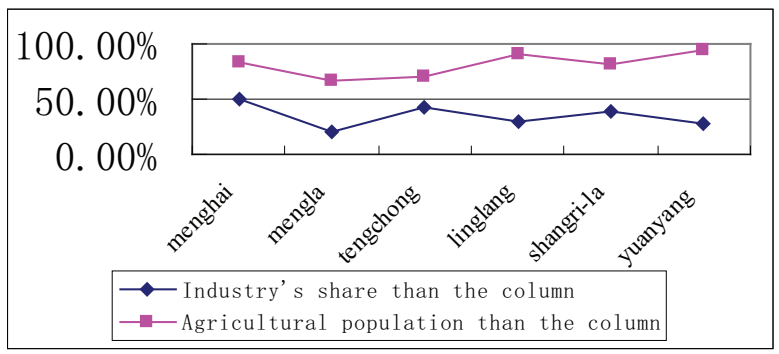

Figure 6. 2011 proportion of industrial and agricultural population trend than the column in six frontier counties of Yunnan

Source: 2012 Yearbook of Yunnan 


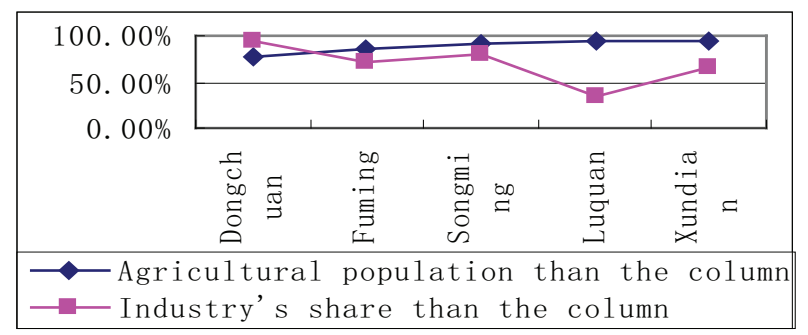

Figure 7. 2009 the proportion of industrial and agricultural population trend than the column in 5 counties of central Yunnan

Source: 2010 Yearbook Kunming

Therefore, industrial development betterthe proportion of the economy accounted for become greater, the more jobs offered to farmers for their urban development initiatively. The proportion of urban residents will greatly enhance, the completion of the whole region urbanization will be better.

\subsection{Solve the problems of economic cost increase of settling in the small town}

Farmers will be based on simple cost - benefit analysis to measure their own pros and cons of the city, small town high prices, spending more than expected, although part of market behavior, but the government still want to play a visible hand of power, try to control the prices of small towns the high, housing ownership alone to solve the housing problems of the farmers into the city is not realistic, small towns to implement low-cost housing policy in Kunming. Small towns should actively build rental housing system, operational security and constantly leasing system. We must also strive to improve the income of farmers into the city, so that farmers can see the benefits are greater than the cost of inputs.

\subsection{Strengthen the infrastructure of small towns and improve quality of nursery, primary school and vocational education}

We must have more concerned about their children to school for peasant household registration changes. It will be a real problem to solve. We can encourage private schools, to ensure that small towns have better kindergarten, and primary and secondary education and vocational needs excellent quality, try to narrow the basic education gap between cities and small towns. Establish standardized educational facilities, standardize the location of kindergarten that go through more stringent screening, so that more kindergarten teachers enter vocational education preschool and change the status quo of uneven quality of preschool teachers. In addition to primary and secondary education, we must improve teaching facilities and pay attention to more comprehensive education for primary and secondary students. To increase the number of vocational education schools, so that more people can receive vocational re-education, which also lay the foundation for better employment.

Sources of funding for the infrastructure of small towns can rely on aspects of national special funds, government financial investment, real estate development companies and bank loans.

\subsection{Gradual weakening social security featur of land and allowing the land to become farmer thrust into the city rather than resistance}

Rural land became the main social security of farmers, social security function of land continued to strengthen, so the primary problem to be solved is the farmers' land issues, and gradually weakening the social security function of land, take the land transfer mode of operation of" combined with government-led and the operation of the market ", so that let the land out from the role of social security. This could be regulate the land transfer from the following aspects and pave the way first. 
Government should highly monopolistic the land rights to purchase and the right to supply, but to prevent corruption in the land.

The implementation of the land deal adhere to an open, fair and just principles.

Practical projects on the government to carry out land acquisition reserves.

Land auctions and planning combined market.

For the transfer of land is important to strengthen the supervision of the entire process can ensure a transparent process open

Safeguard the interests of farmers earnestly, so that the land became a powerful force farmers into the city rather than resistance.

\section{References}

1. Zhang Zulin, 2012 Kunming city government work report, January 11, 2012.

2. Zhao Junchen, Kunming global Several Problems of urbanization, China Reform Forum Network, October 14, 2012.

3. Miao Rui-qing, Rong Jian, Zheng Shuhua,rural labor transfer speed and the number of influencing factors, China Rural Survey, 2004.2.

4. "Urbanization of Rural Labor Transfer Research "Task Force,Urbanization of rural labor transfer: strategic choices and policy thinking, China's rural economy, 2011.6.

5. Yin Xi guo, Ma dalai, the affecting willingness Factors Analysis to participate in the reform of the household registration system, China Rural Survey, 2012.1.

6. Chen Binkai, Lu Ming,Zhong Ninghua, residents consumption under the household registration system restriction, economic research, 2010.

7. Li Ruojian, small towns and small towns demographic household registration system reform, population and economic 2002-4.

8. Reporter observed: farmers to the city need to focus on something behind domicile, Yunnan Network June 12, 2012.

9. Zhu Baoshu,study on new issues of household registration system reform and rural urbanization of small towns, East China Normal University, 2004-9. 